\title{
The Impact of Translators on Mainstream During Conflicts
}

\author{
Aya KAYED $D^{l}$ \\ Veysel KILIÇ ${ }^{2}$
}

\begin{abstract}
Translators and interpreters play different roles during conflicts which affect the narrative of the conflicts and public opinions. In today's world of conflicts and wars, the need for translators and interpreters has become necessary to perform different tasks including linguistic mediation between the parties of conflict. In this light, there is a need to study the role of translators during conflicts and its impact. The analysis of primary and secondary sources was the material of this qualitative paper. It investigates the role of Iraqi translators and interpreters who covered the US war on Iraq and/ or worked with the US forces in Iraq. It was found that translators largely contribute to the shaping of the conflict narrative in many ways including translation. Hence, their contribution leads the audience to certain interpretations which draw the public mainstream. It also argues that each decision - whether translational or acceptance of an assignment - translators made has consequences that affect their personal and professional lives, and that - in such situations - they cannot be neutral, i.e. they must position themselves.
\end{abstract}

Keywords: Narrative, Translators and Interpreters, Conflict, Mainstream

\section{ÖZ}

Çevirmenler, çatışmalarda, çatışmaların ve kamuoyu yoklamalarının dile getirilme şekli üzerinde büyük etkileri olan farklı roller üstlenmektedir. Günümüz dünyasının çatışma ve savaş ortamında, çatışan taraflar arasındaki sözlü veya yazılı iletişimin tesis edilmesi dâhil çok çeşitli görevlerde çevirmenler büyük

\footnotetext{
${ }^{1}$ Istanbul Aydin University, Istanbul, ayakayed@stu.aydin.edu.tr, https://orcid.org/0000-0002-1087-3652

${ }^{2}$ Prof. Dr., Istanbul Aydin University, Istanbul, vlkilic@aydin.edu.tr, https://orcid.org/0000-0002-6773-9307

Research Article - Submit Date: 14.09.2020, Acceptance Date: 24.01.2021

DOI: 10.17932/IAU.IJMCL.2015.014/ijmcl_v07i1001
} 
önem kazanmaktadır. $\mathrm{Bu}$ bakımdan, çevirmenlerin çatışmalar sırasında üstlendikleri rolün ve bu rolün etkisinin araştırılması büyük önem taşımaktadır. $\mathrm{Bu}$ nitel çalışmada, Amerika Birleşik Devletleri'nin Irak'a yönelik harekâtı boyunca harekâtla ilgili çeviriler yapmış ve/veya Birleşik Devletler'in silahlı kuvvetleri için çalışmış Iraklı çevirmenler incelenmiş ve incelemede birincil ve ikincil kaynaklardan faydalanılmış olup çevirmenlerin, çatışmaların dile getirilme şekline gerek çeviri yoluyla gerekse farklı yollarla katkıda bulundukları görülmüştür. Bu bakımdan, sundukları katkılar, dinleyici/okuyucu kitlesinin, ana akımın dikkatini çeken farklı yorumlarda bulunmasına neden olmaktadır. Ayrıca, ister çeviri ile ister bir görevin kabul edilmesi ile ilgili olsun, çevirmenlerin verdiği her kararın kişisel ve mesleki hayatlarını etkileyen sonuçlar doğurduğu ve bu gibi durumlarda tarafsız kalamadıkları, başka bir deyişle taraf seçtikleri görülmüştür.

\section{Anahtar Kelimeler: Anlatı Teorisi, Çeviri, Savaş, Popüler Akım}

\section{INTRODUCTION}

Each war has its own actors, who control its path and narrative. From the moment the war is declared until it ends, it takes the form of a linguistic act. This includes the involvement of language mediators such as translators and interpreters. They are considered one of the parties involved in the war because of their role in building the narrative connecting the parties of the conflict, which the audience receives and reaches through the news or through daily events in real life. This participation defines the description of translators and attributing them to one of the two conflict camps. It has several implications - positive or negative - for them. A group of active translators who engage in this work in order to defend a cause may be classified using language and their various translation and linguistic skills. It is also possible through the narrative theory to trace the translation work and translated materials and analyze them politically, socially and linguistically to study this role.

Nowadays, the role of language mediators, namely translators and interpreters, has got great attention. Many studies investigate their impact on the public mainstream and their contribution to the elaboration of conflict narrative. Among the current researchers who studied the relationship between translation and conflicts is Mona Baker. Her works $(2006,2007)$ draw basically on the narrative theory and the notion of framing to study how translators and interpreters take part in the construction of social and political reality. However, in conflict zones, translators may not only perform translation tasks in its technical definition. They might be recruited to do other jobs using their translation and language skills, by which neutrality will be impossible (Palmer, 2007). Accordingly, whatever the 
situation is, once the translators make a decision, they will be judged and labelled by all parties in a certain conflict arena (Inghilleri, 2010).

Language is considered as a basic tool in conflicts, as it is used in the discourse announcing the start of a conflict, and then comes the role of translation as a channel of communication between the parties through translators. Through this process, translators as language mediators participate in shaping certain narratives that compete with a dominant one. Studying the narrative theory, its definition, types, and applications can help understanding how they do so. However, this participation comes with a price: there is no place for neutrality in such situations, and translators to be belonging to one of the conflict camps. Yet, they still will be judged regardless of their decision or the circumstances that led to that decision.

Throughout contemporary history, translators and interpreters' role was hidden. Yet, they were major actors and moderators of warpath and its narrative. What are the different roles they played in conflict zones? How do these roles contribute to the drawing of conflict's narrative and labeling translators and classify them accordingly? There is an urgent need to study the tasks performed by translators and interpreters due to the expansion of the conflict zones around the world and the increasing number of translators who study translation or practice it on site. In this article we will look at the different roles of Iraqi translators who took part during the US invasion in Iraq, how they affect the story of conflict, and how their lives were effected as well. It also argues that the role of translators is not limited to the language mediation and coding and decoding of texts, but exceeds it to the actual participation in politics, activism, and documentation using their basic tool - i.e. language.

\section{TRANSLATION AND CONFLICT}

From the very beginning of a war, it takes a linguistic form. Its announcement is written and/ or declared in the languages of conflicting parties. This form of communication is both linguistic and verbal in its own (Chilton, 1997). That ensures the importance of language as one of the war tools. However, to process and understand this language, a kind of mediator is needed, especially when the conflicted parties are speakers of different languages. Mostly, they need a third party to communicate, such as translators and interpreters. Translation or the communication channel of translators or interpreters occupies a key position during wars and conflicts. They have unpredicted translational abilities in orienting the narration of war. They shape its story using linguistic strategies, that is why they are considered as actors in the war along with other parties who manage the conflict or align it. 
Baker (2006) studied the relationship between translation and conflicts -armed and political ones - based on the narrative theory. She defines the word narrative as the detailed stories of our daily lives which we tell or write. These narratives or stories build our views of the world and the way we conceive it. In the context of conflicts, narrative involves our views of the actors in these conflicts or wars - particularly, translators and interpreters. From her point of view, language is the most powerful tool at all times. A competent translator knows when and how to use it whether for his/ her own favor, or even for the favor of the side he/ she represents - especially during conflicts. The result is an elaboration representing the conflict; translation is the linguistic monitor that modifies or adjusts the narrative to meet the target addressees implicitly (Briggs, 1996).

Narratives like social movements, have a specific cause that they defend or circulate at different levels, and both share almost similar topics during critical times. When a number of people find themselves having a common problem, they gather themselves to find a solution, or raise awareness on it in an automatic way. More importantly, those people, often, do not know each other, and they may have different backgrounds. This unintentional mobilization movement is considered one of the narratives' strengths (Baker, 2006). However, as our experiences change, narratives change. That reflects their crucial impact on translation in regards to the type of materials selected to be translated, for example, but not limited to them. The selected material also tells a lot about the translator, his/ her identity, thoughts, language attitudes, or political orientations.

Somers and Gibson (1994) divided narratives into four kinds:

1. Ontological narratives: are personal stories circulating around the "I" and "Me".

2. Public narratives: are stories at the level of a group of people rather than the individual. Such kind of narratives should answer the why, what, and when questions.

3. Conceptual narratives: are stories and explanations that have been constructed by scholars. These conceptual narratives or stories can have an impact on the world.

4. Meta narratives (master narratives): are the largest circle of stories. They involve all of us in the story where everyone plays a role in history.

"War on Terror" is a public narrative that has a direct impact on the world. It is considered a good example of the meta narrative (master). The word "terror" means a state of mind that can cross boundaries. It has meta-narrative characters with temporal and physical features. While the word "terrorism" means the use 
of violence and intimidation in the pursuit of political aims. ${ }^{1}$ The choice of the word "terror" can fit easily with political agendas, and its impact is a good example of circulation and adoption of a narrative. However, a meta or master narrative has a direct relationship with language mediators. The more their number increases, the better the chances are to build an alternative narrative that can cross the world and compete with the dominant narratives. On the one hand protests, sit-ins, demonstrations, votes and rallies are forms of challenging domination on a local level, but on the other hand translation performs this role on a global level in the form of linguistics (Baker, 2006). In order for those ways of expressions to be circulated widely, they need to be translated to all possible spoken languages.

The activism communities of translators and interpreters reveal the importance of the narrative theory by examining the type of narrative they elaborate, and through asking how they mediate these narratives in terms of the selected materials to be translated and the adopted mode of translation (Baker, 2006). This examination also helps to inspect the interventions made by the translators, and to which degree their work is neutral and objective. Otherwise, translators may be labeled as "biased" and "untrustworthy" which affects the credibility of their own narratives. In this sense, accuracy becomes more important.

In today's world of conflict, it is challenging to be neutral. Translators and interpreters find themselves a part of this web of confrontations and in need of positioning themselves. In addition, they participate consciously or unconsciously in the circulation of narratives set out by activists and suppressed communities, shaping the public's mainstream. In this sense, translation empowers those language mediators - by using linguistic strategies — to reproduce alternative narratives that compete with the world dominant ones. Hence, they group together to cross global boundaries as they start to understand their crucial impact at a global level by controlling over the mainstream of public (Baker, 2006).

\section{HOW DO PEOPLE CONCEIVE TRANSLATORS DURING CONFLICTS?}

When translators and interpreters accept an assignment related to the conflict, they will be associated with one of the two conflicting camps: the $U_{s}$ camp or the Other camp (Baker, 2010). In addition, they will be considered as one of the war actors from different perspectives. Ethical questions about their role will be elaborated, and they, accordingly, will be judged based on the verbal and linguistic choices they make. The unwilling participation of language mediators

1 Oxford dictionary of English 
during conflicts and wartimes has consequences on their and their families' lives and safety. In the following part, we will see how did people conceive Iraqi translators who performed translation and other related tasks during the US invasion of Iraq, and how they had been treated.

On 19 March 2003, a combined force of troops, from the United States, United Kingdom, Australia, and Poland, led by the US invaded Iraq with aims to disarm Iraq of mass destruction weapons, fight terrorism, and free Iraqi people according to the US former President George W. Bush. The US forces hired tens of thousands of Iraqis to work with them as interpreters or to do other jobs. ${ }^{1}$ Hundreds of them have been killed, and many others have faced threats and attacks for working with the US forces - the enemy camp, even those who worked for international agencies that covered the war in Iraq. Some have been labeled as untrustworthy, traitors, collaborators, and many other names (BBC, 2007). Others fled Iraq to Europe to protect themselves as the US failed to keep its promise to grant them humanitarian and refugee visas to the country as the case with the Iraqi former interpreter Shaker Jeffrey, who fled to Germany awaiting the US visa for more than a decade. ${ }^{2}$

There are many stories of Iraqi interpreters like Jeffrey's, whose lives have been changed since then. From Iraqi interpreters' perspective, they were just doing their jobs as language mediators. While from the locals' point of view, working with that whom they consider an enemy, regardless of what kind of work one does, is an ethical and social matter, in which they will be judged accordingly. Indeed, many people and institutions including military personnel, the media, and the audience take part in drawing the general picture of these mediators labeling them as traitors, victims, heroes, or simply employees. In addition to the linguistic and cultural judgements, translators are facing ethical and political issues. Questions about their roles during conflicts in such positions come to the surface.

On the legal level, some translators and interpreters have been investigated for taking part during interrogations in Guantanamo and Abu Ghraib in Iraq and witnessing abuses and violations to the Geneva Convention (Williams, 2006; Saar and Novak, 2005). They have been questioned about their role there. While others such as Adel Nakhla, an Egyptian-American translator was hired by Titan Corporation, ${ }^{3}$ has never been prosecuted. Instead, he had been terminated by the company after the scandals of Abu Ghraib prison as he accused of humiliating

\footnotetext{
1 Source: https:/www.nbcnews.com/news/world/only-2-iraqi-translators-who-workedu-s-troops-got-n1035661

2 Source: Ibid

3 Titan Corporation, located in San Diego, received a contract awarded by the US Army to hire Arabic translators and provide translation services
} 
abuses. ${ }^{1}$ When it comes to a public concern within a society translators refer to, they cannot escape their social and ethical duty. They have to make a decision and position themselves even if they are not obliged to do so.

Yet, some positions are sensitive enough to make the decision obligatory. In order to overcome this issue, Levinas (1989) suggests that it is important to organize and put down a just structure by the law for making decisions, regarding sensitive cases, without interfering with one's ethics. That is having a code book related to such cases will help to mitigate the consequences. However, the professionality of a person becomes less important in comparison to the ethical questions in terms of sensitive issues. A translator has to resolve these issues alone, either by choosing to be with the "Other" camp or with the "Us" camp, where the two parties are on the stage. In the battlefield, a quick reaction is the only thing to do, instinctively. Thinking of what should be done appropriately is not a choice in the middle of a fight. Yet, whatever the decision is, it is still the one choice that can be taken and known at that very moment (Inghilleri, 2008).

\section{THE IMPACT OF TRANSLATORS ON THE PUBLIC NARRATIVE OF WAR}

Today, translators and interpreters are not just rendering texts. Indeed, they become actual actors in geopolitical arena by employing the language for different purposes. Their role is not just limited to the traditional and technical meaning of translation. They, now, influence the way the war is narrated, for they have a considerable space to perform their tasks immediately. As well, they have freedom to restate what others said briefly, as they understood. In addition, they may perform other kinds of tasks rather than linguistic mediation. However, despite all the ups and downs translators are being through during conflicts, they are still the ones who put the pieces of the puzzle together for history, media and narrators.

The international agencies that covered the war in Iraq hired Iraqi interpreters to work side by side with the foreign journalists there. This cooperation between foreign journalists and Iraqi interpreters affected the elaboration of the war narrative in many different ways but kept the control of its path within the hands of Iraqis as the translators reproduced and strengthened a certain narrative on the war. For example, the multiplicity of religious sects in Iraq and the sectarian division of cities have served the conflicting parties (Palmer, 2007). That led the journalists to different conclusions regarding the war in Iraq and its narrative by how translators stated this sectarian division. For instance, Sunnis could not enter some Shia's areas, where they could not feel safe and vice versa. Therefore, they

1 Source: https://www.wsj.com/articles/SB108518649426918483 
will have a restricted range of narratives. While refusing or accepting to cross some sectarian boundaries by interpreters emphasizes or diminishes the sectarian division in Iraq.

With the increased violence in Iraq since March 2003, 360 Iraqi translators and interpreters were killed, and more than 1200 wounded between 2003 and 2008. ${ }^{1}$ In addition, 36 journalists were killed since the beginning of the war until October 2004 (Palmer, 2007). This makes the situation for foreign journalists too dangerous to work on site. Instead, they hired Iraqis with translation skills to work as sources or journalists for these agencies to ensure the flow of information. Questions about the reliability of the information transmitted have been raised. Many doubts the trustworthiness of Iraqi journalists and co-workers and misleading information they gave (Marting, 2004).

Concerning defining the role of translators, there are two suggested perspectives. The first one is how the participants in a war zone defines them - as discussed above. The second is how the translators and interpreters define their roles in these situations and to which extent they participate in elaborating public narratives according to Baker (2010). When the translators take a position, there is no in-between space, and there will always be consequences. She discussed the concepts of difference and homogeneity that characterize translators in terms of the camps they belong to during conflicts. These two concepts - difference and homogeneity - can have an effect on translators and interpreters at their workplace; how their co-workers and employers define them. Accordingly, this will have an impact on the elaboration of public narratives of wars. In other words, labeling translators during conflicts has an impact on the warpath and its narrative.

Translators and interpreters ${ }^{2}$ are labeled as either "trustworthy" or a threat to security by the "enemy" camp or even by their societies. In terms of Iraqi translators and interpreters, they were judged for using their native language in favor of the enemy, when they had to shut down any chance of cooperation. The translators who chose to work in the interest of foreigners or with the invading forces are traitors - to locals - and deserve to be treated and judged like the invading army — namely they are not victims in this context (Rafael, 2007).

Moreover, the proficiency level of translators' own language is another factor that influences the public narrative, in addition to their professional experience in terms of their ability to deal with the subtle differences in meaning and linguistics. Translators and interpreters with very short experience may face difficulties in

\footnotetext{
1 Source: Ibid

2 Translators and interpreters of wars are widely known now as "fixers" due to the multiple tasks they perform
} 
conveying the exact meaning. In this sense, different narratives of the war will come up, and the question is not about if it is true or false; rather, it is about how it will influence the path of war and mainstream.

\section{CONCLUSION}

Everyone is involved in the war machine, including translators and interpreters. In times of conflict, translators contribute significantly to shaping and building the narrative of war in many forms by using their translation skills to perform many tasks besides translation. They contribute, for example, to building a conscious or unconscious image for the reader about the barbarism of the other side, "the enemy's camp", and highlighting it as a criminal. On the other hand, it affects the reader by activating his/her feelings of sympathy for the victim (highlighted by the translation) and push the reader to adopt a specific view of who the victim and who the killer is. However, translators' perspectives may emerge through their translation choices, their linguistic level and skill, which is reflected in their texts and thus in the narrative. But despite these two important roles - narrative building and influencing the audience - translators pay a great price for this that may cost them their lives. It is possible for the community to call the translator a "hero" if he/she performs a task or completes a translation that matches the direction of the society. The translator could also be accused of treason and his/her life being threatened.

\section{REFERENCES}

Baker, M. (2006) Translation and Activism Emerging Patterns of Narrative. The Massachusetts Review, 47(3).

Baker, M. (2006). Translation and Conflict: A Narrative Account. Routledge Taylor \& Francis Group.

Baker, M. (2010). Interpreters and Translators in the War Zone: Narrated and Narrators. The Translator, 16(2).

BBC Radio Four. (2007) Face the Facts: Iraqi Interpreters, 20 July. Available at http://www.bbc.co.uk/radio4/facethefacts/transcript_20070720.shtml.

Briggs, C. (1996). Disorderly Discourse: Narrative, Conflict, and Social Inequality. Oxford University Press.

Chilton, P. (1997). The Role of Language in Human Conflict: Prolegomena to the Investigation of Language as a Factor in Conflict Causation and Resolution. Current Issues in Language \& Society, 4(3). 
Inghilleri, M. (2008). The Ethical Task of the Translator in the Geo-Political Arena. Translation Studies, 1(2).

Inghilleri, M. (2010). You Don't Make War Without Knowing Why: The Decision to Interpret in Iraq. The Translator, 12(2).

Levinas, E. (1989). Ideology and idealism. In S. Hand (Eds), The Levinas Reader (pp. 235-260). Oxford: Basil Blackwell.

Marting, S. (2004). Shortage of interpreters foreshadowed prison excesses. The St Petersburg Times. Available at: www.globalsecurity.org/org/news/2004 /040520-interpreters-

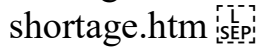

Palmer, J. (2007). Interpreting and Translation for Western Media in Iraq. Translating and Interpreting Conflict, 28, 13-28.

Rafael, L. (2007). Translation in Wartime. Public Culture, 19(2).

Saar, E. \& Novak, V. (2005). Inside the Wire: A Military Intelligence Soldier's Eyewitness Account of Life at Guantánamo. The Penguin Press.

Somers, R. \& Gibson, G. (1994). Reclaiming the Epistemological 'Other': Narrative and the Social Constitution of Identity. Oxford: Blackwell.

Williams, K. (2006). Love My Rifle More Than You: Young and Female in the US Army. London: Weidenfeld \& Nicolson.

Marting, S. (2004). Shortage of interpreters foreshadowed prison excesses. The St Petersburg Times. Available at: www.globalsecurity.org/org/news/2004 /040520-interpretersshortage.htm is[ip? 